\title{
Pharmaceutical Wastes Management and the Presence of Pharmaceuticals in the Environment of Health Facilities in Lagos State, Nigeria
}

\author{
Article by Afusat Adesina ${ }^{1}$, Sanni O. Felix ${ }^{2}$ \\ ${ }^{1}$ Howard University Global Initiative Nigeria, Lagos \\ ${ }^{2}$ Chemistry Department, Federal University of Agriculture, Abeokuta \\ E-mail: afusatgain@gmail.com
}

\begin{abstract}
Environments continuously receive mixtures of drugs on a global scale. The most popular uses of drugs include human medicine as tools for the treatment or prevention of various diseases, veterinary drugs or husbandry growth promoters with applications on many different aspects of agriculture. Objectives of this study are to identify the major methods used in PWM in the health facilities in Lagos state, Nigeria and to identify the presence of pharmaceutical in the environment. This study comprised 376 respondents of which $68.4 \%$ were females. Most frequent age range was 31 - 40 years, (42.3\%). $43.4 \%$ have been in service between 1-5 years. $34 \%$ work in general hospitals while $8.0 \%$ work in comprehensive health centers. Majority (37.5\%) dispose pharmaceutical wastes in medical waste bin. Unused drugs are mostly returned directly to the supplier (40.4\%) while expired drugs are mostly returned to manufacturers (41.2\%). Most facilities dispose wastes in biohazard bags (red, 19.95\%, yellow and black, 19.68\%). 0.634ug/L of amoxillin trihydrate was detected in waste water and $6.791 \mathrm{ug} / \mathrm{g}$ in sludge. $0.203 \mathrm{ug} / \mathrm{L}$ of Clavlnic acid was present in tap water, $0.264 \mathrm{ug} / \mathrm{L}$ of Ciprofloxacin Hydrochloride was found in waste water and $6.353 \mathrm{ug} / \mathrm{g}$ in sludge. Diclofenac was $0.409 \mathrm{ug} / \mathrm{L}$ in wastewater. Paracetamol concentration was $0.00379 \mathrm{ug} / \mathrm{L}$ in tap water, $0.01196 \mathrm{~g} / \mathrm{L}$ in waste water and $0.55768 u g / L$ in sludge. It is concluded that the presence of pharmaceutical wastes in tap water, waste water and sludge in hospital environments is connected with waste management methods. Awareness and training are necessary to avoid environmental pollution of pharmaceutical wastes.
\end{abstract}

Keywords: Wastes, drugs, Pharmaceutical Waste management, Healthcare workers, Environments, hazards.

\section{Introduction}

According to WHO (2017) "guideline on Safe management of waste from healthcare activities" pharmaceutical waste includes expired, unused, spilt and contaminated pharmaceutical products, prescribed and proprietary drugs, vaccines and sera that are no longer required, and, due to their chemical or biological nature, need to be disposed of carefully (WHO, 2017). The group also includes items discarded during the handling of pharmaceuticals, such as bottles, vials and boxes containing pharmaceutical residues, gloves, masks and connecting tubing's (Jovanović et al., 2016). Pharmaceuticals have been reported to be present in waste water, surface ground and drinking water. More than 80 pharmaceuticals were detected in sewage, ground and surface water to the level of some $\mu \mathrm{g} / \mathrm{L}$ and traces in drinking water in studies carried out in ten countries (Priya, 2017). Pharmaceutical wastes from effluents have been found to have acute and chronic health risks. Behavioral changes, accumulation in tissues, reproductive damage and inhibition of cell proliferation are some of the health risks (Patneedi et al., 2017).

The persistence and exposure of a wide range of antibacterial substances observed in waters could possibly result in the formation of resistant microbes, which could pose a serious threat to human and animal's health. The major sources of health care waste are hospitals, pharmaceutical waste which are generated during provision of health care services to patients and they are class of healthcare waste that belongs to the hazardous healthcare waste stream (Jovanović et al., 2016). The exposure routes of pharmaceuticals into the environment are the manufacturing unit, hospital effluents and land application etc. Sewage treatments are not successful in removing active chemicals from waste water, hence pharmaceuticals get into the aquatic environment and they directly affect the organism. In a study in India, the extraordinarily high levels $(\mathrm{mg} / \mathrm{L})$ of several drugs were found in the effluents from local 
wastewater treatment plant near Visakhapatnam in India. Studies on antibiotics have shown that up to 95\% of antibiotic compounds can be released unaltered into the sewage system. Non-steroidal antiinflammatory drugs (NSAIDs), like ibuprofen, naproxen and diclofenac are widely being used and consequently are frequently detected in sewage, surface water and may be found in ground water system (Patneedi et al., 2017). To dispose pharmaceutical waste, recommendation is based on the pharmaceutical product formulation or the category of chemicals (Priya, 2017).

In Nigeria, not many people are aware that pharmaceutical waste contributes substantially to environmental pollution and hazards. This is reflected by lack of awareness and specific policy to address the menace of pharmaceutical waste. Sources of pharmaceutical waste includes human sources such as excretion, drugs dumped into toilets and sinks, effluents discharging from waste-water treatment plants that are not capable of removing the medications, landfill leachate (medications discarded in trash), and septic systems

Pharmaceutical wastes can be managed using Incineration, Microwaving, Deep burial, Secure land filling, Waste immobilization: encapsulation, Inertization etc. Objectives of this study is to identify the major methods used in the management of pharmaceutical wastes in the health facilities in Lagos state, Nigeria and to identify the presence of pharmaceutical wastes in waste water, tap water and sludge in the environment of one of the major health facilities.

\section{Methodology}

\section{Study area}

Lagos is an administrative and commercial center of Nigeria, located in the Southwest of the country. It is the smallest in terms of land space, but the second most populous state and the most economically important state of the country, and also the second fastest growing city in Africa and the seventh fastest in the world. The population is an estimated 21 million (2011) which is $10 \%$ of Nigeria's population, recently projected at 167 million by the National Population Commission. Lagos is a large metropolis. The social, economic, political and commercial reality of the nation finds their relevance in Lagos. No other city in Nigeria has the blend of all the attributes that is in Lagos. Lagos is ranked among the least live-able cities in the world. If on the average every inhabitant generates just $1 \mathrm{~kg}$ of refuse per day, it means that, in a day we have 12 million $\mathrm{kg}(10,800$ tons) and therefore, in a month, a volume 302,400 tons of refuse will be generated, including the pharmaceutical wastes.

According to Healthcare Facilities Monitoring and Accreditation Agency (HEFAMAA, 2016), an Agency of Lagos State Ministry of Health, there are registered: 26 General Hospitals, 256 Public Healthcare Centers.

\section{Study population}

The target population of this survey consisted of selected 376 healthcare workers in all the health facilities. The healthcare workers for the purpose of this study are those who deal directly or indirectly with medicines. To be included in this study, the Healthcare Workers (HCWs) must be involved with handling of pharmaceuticals and the health facility must be located in selected local government in Lagos State. Any facility that did not meet the inclusion criteria was excluded.

\section{Data collection}

Data were collected using self-developed anonymous structured questionnaires, containing open and closed-ended questions. The questionnaires had sections on demographic characteristics, health facilities information and methods adopted by healthcare workers to dispose pharmaceutical waste. The questionnaire was validated prior to administration to $\mathrm{HCW}$ by using 30 healthcare workers from one of the local governments (LGA) also within Lagos State that is not in the selected LGA for the preliminary study.

\section{Ethical consideration and participants consent}

Ethical approval for this study was sought and obtained from Lagos State University Teaching Hospital (LUTH) and National Orthopedic Hospital Igbobi (NOHI) Health Research and Ethics Committee (HREC). The approval for permission to participate by the health care workers was also 
obtained from the Health Service Commission, (HSC) Lagos state. The procedures were explained to the individual participants and thereafter their consent to participate in the study was obtained. The participants that declined not to be part of the study were excluded. Confidentiality was ensured by excluding all the names of the hospital and individual surveyed.

\section{Sampling technique}

The required sample size was obtained by using a multistage sampling technique. Four local governments were selected by simple random sampling from the twenty local governments that exist in Lagos State. Two Local governments were randomly picked from Lagos West, one randomly picked from Lagos Central and Lagos East. All the public health facilities in each of this LGA were clustered as (tertiary, secondary and primary). The health facilities were selected using stratified sampling methods. Questionnaires were administered to all the health workers in each of the selected health facility.

\section{Analysis of selected pharmaceuticals in water}

Selected pharmaceuticals: The following medicines were selected based on their possibility of being detected in waste water: Paracetamol, Diclofenac, Ciprofloxacin and Amoxicillin/Clavulanic acid.

\section{Sample preparation for tap / waste water}

Sludge, tap and waste water samples were collected from the environment of a tertiary health institution (Lagos state university teaching hospital), the tap water was collected from bore-hole water system, and waste water was collected from a pipe. The tap water and waste water were transported to the laboratory in transparent plastic bottles and stored in a refrigerator below $0^{\circ} \mathrm{C}$ until analysis. Tap/Waste Water samples were allowed to thaw and filtered using a Whatman filter paper diameter $18 \mathrm{~cm}$ to remove suspended particles. For tap water, $10 \mathrm{~mL}$ of $0.1 \mathrm{M}$ disodium-EDTA solution was added to a $1 \mathrm{~L}$ volumetric flask already containing $200 \mathrm{~mL}$ of filtered tap water. The solution was shaken vigorously and made up to the mark with the filtered tap water. For waste water, $5 \mathrm{~mL}$ of $0.1 \mathrm{M}$ disodiumEDTA solution was added to a $500 \mathrm{~mL}$ volumetric flask already containing $100 \mathrm{~mL}$ of filtered tap water. The solution was stirred vigorously and made up to the mark with the filtered tap water.

*disodium-EDTA is a chelating agent that binds with metals such as Calcium and Magnesium in the water sample, preventing such metals from binding with antibiotics.

\section{Sample preparation for sludge}

The sludge was obtained from a flowing drainage system .and transported to the laboratory in dark containers stored in an ice-packed cooler. Samples were refrigerated. Samples were homogenized and percentage (\%) moisture content analysis was carried out on each sample.

Based on the $\%$ moisture content of each sample, an equivalent of $2 \mathrm{~g}$ (dry weight) was weighed and transferred to a $50 \mathrm{~mL}$ glass centrifuge tube. $10 \mathrm{~mL}$ of already prepared Mcilvaine buffer (pH: 4.0) was added and vigorously shaken for 5mins, allowed to stand for sedimentation and the supernatant was collected into a $100 \mathrm{~mL}$ volumetric flask. The residue was further washed with $10 \mathrm{~mL}$ of Mcilvaine buffer, allowed to stand and the supernatant added into the $100 \mathrm{~mL}$ volumetric flask above. $5 \mathrm{~mL}$ of $0.1 \mathrm{M}$ $\mathrm{Na}_{2}$-EDTA solution was added to the volumetric flask, shaken and made up to the mark with distilled water. The extract was filtered with a Whatman filter paper diameter $18 \mathrm{~cm}$ to remove suspended particles. The filtrate was stored below $4^{\circ} \mathrm{C}$ prior to solid phase extraction (SPE).

\section{Solid phase extraction (SPE) step}

HyperSep Retain Polar Enhanced Polymer (PEP) SPE cartridges (200 mg, 6mL) were used for extraction effluent wastewater samples on a Supelco Visiprep SPE Vacuum Manifold (standard, 24port model). Three (03) SPE Cartridges were first conditioned with $6 \mathrm{~mL}$ Methanol, followed by $6 \mathrm{~mL}$ distilled water. A $1000 \mathrm{~mL}, 500 \mathrm{~mL}$ and $100 \mathrm{~mL}$ of tap water, waste water sample and sludge extract were loaded onto separate SPE cartridges followed by a wash step of $6 \mathrm{~mL}$ water to further remove possible traces of disodium-EDTA and any unwanted interferences. The cartridges were allowed to dry. Bound actives were subsequently eluted with $4 \mathrm{~mL}(2 \times 2 \mathrm{~mL})$ Methanol into salinised amber glass tube. 
Eluted extracts were evaporated to dryness under a gentle stream of $\mathrm{N}_{2}$ and reconstituted in $0.5 \mathrm{~mL}$ of Methanol. Extract solutions were stored in amber glass vials at $4{ }^{\circ} \mathrm{C}$ and in the dark towards HPLC analysis.

*Glassware used for extraction of wastewater samples was salinised to reduce analyte adsorption to glass surfaces. This procedure included an initial rinse with 50:50 (v/v) methanol- water before triplicate rinses with dichloromethane.

\section{High performance liquid chromatography (HPLC) analysis}

\section{a. Preparation of calibration standards for diclofenac}

$10 \mathrm{mg}$ of Diclofenac was weighed into a $100 \mathrm{~mL}$ volumetric flask and mixture of Methanol: Water (700:300) was used as diluent. A stock solution of $0.1 \mathrm{mg} / \mathrm{mL}(100 \mathrm{ug} / \mathrm{mL})$ was prepared by making up to the mark with diluent. Lower concentrations of calibration standards $(2,1,0.5,0.25 \mathrm{ug} / \mathrm{mL})$ were prepared from the stock solution and transferred to HPLC vials for analysis.

\section{b. Preparation of calibration standards for ciprofloxacin HCL}

$10 \mathrm{mg}$ of Ciprofloxacin $\mathrm{HCl}$ was weighed into a $100 \mathrm{~mL}$ volumetric flask and water was used as diluent. A stock solution of $0.1 \mathrm{mg} / \mathrm{mL}(100 \mathrm{ug} / \mathrm{mL})$ was prepared by making up to the mark with diluent. Lower concentrations of calibration standards $(10,5,1,0.5 \mathrm{ug} / \mathrm{mL})$ were prepared from the stock solution and transferred to HPLC vials for analysis.

\section{c. Preparation of calibration standards for paracetamol}

Paracetamol $(10 \mathrm{mg})$ was weighed into a $100 \mathrm{~mL}$ volumetric flask and mixture of Methanol: Water (1:3) was used as diluent. A stock solution of $0.1 \mathrm{mg} / \mathrm{mL}(100 \mathrm{ug} / \mathrm{mL})$ was prepared by making up to the mark with diluent. Lower concentrations of calibration standards $(2.5,1.25,0.25,0.05 \mathrm{ug} / \mathrm{mL})$ were prepared from the stock solution and transferred to HPLC vials for analysis.

\section{d. Preparation of calibration standards for amoxicillin trihydrate and clavulanic}

An equivalent of $20 \mathrm{mg}$ and $10 \mathrm{mg}$ of Amoxicillin and Clavulanic acid respectively was weighed from a secondary standard into a $100 \mathrm{~mL}$ volumetric flask and distilled water was used as diluent. A stock solution of $0.1 \mathrm{mg} / \mathrm{mL}(100 \mathrm{ug} / \mathrm{mL})$ was prepared by making up to the mark with diluent. Lower concentrations of calibration standards $(20,4,2,1,0.5 \mathrm{ug} / \mathrm{mL})$ were prepared from the stock solution and transferred to HPLC vials for analysis.

\section{Data analysis}

Statistical Package for Social Sciences (SPSS version 20) was used for the analysis of the data. ChiSquare statistical test of significance was used to determine the level of significance of association between variables at $95 \%$ confidence level. Level of significance was set at $\mathrm{p} \leq 0.05$.

\section{Results and discussion}

Respondent background information included sex, age category, years in practice and place of work as shown in Figure 1. There were 376 respondents of which 119 (31.6\%) were males and $257(68.4 \%)$ were females with Male: Female ratio of 1:2. The mean age was $37 \pm 10$ years with minimum and maximum of 18 and 76 respectively. The most frequent age group was $31-40$ years with $159(42.3 \%)$ respondents followed by $109(29.0 \%), 62(16.5 \%)$ and $40(10.6 \%)$ seen for age groups $21-30,41-50$ and above 50 respectively while the least value of $6(1.6 \%)$ was seen for 20 years and below. Most of the respondents, $126(33.5 \%)$ work in general hospitals followed by $72(19.1 \%)$ for tertiary hospitals. $52(13.8 \%)$ were from specialist hospitals, $44(11.7 \%)$ from basic health centres, $36(9.6 \%)$ from private hospital while $30(8.0 \%)$ and $16(4.3 \%)$ were from comprehensive health centres and other health institutions respectively. Most of the respondents, 126 (33.5\%) work in general hospitals followed by $72(19.1 \%)$ for tertiary hospitals. $52(13.8 \%)$ were from specialist hospitals, 44 (11.7\%) from basic health centres, $36(9.6 \%)$ from private hospital while $30(8.0 \%)$ and $16(4.3 \%)$ were from comprehensive health centres and other health institutions respectively. 
Table 1. Socio-demographic characteristics of the Respondents $(n=376)$

\begin{tabular}{lll}
\hline Parameter & Frequency & Percentage \\
\hline Gender & 119 & 31.6 \\
Male & 257 & 58.4 \\
\hline Female & & \\
\hline Age Category & 6 & 1.6 \\
20 \& below & 109 & 29.0 \\
$21-30$ & 159 & 42.3 \\
$31-40$ & 62 & 16.5 \\
$41-50$ & 40 & 10.6 \\
Above 50 & & \\
Health facility & 72 & 19.1 \\
Tertiary Hospital & 126 & 33.5 \\
General Hospital & 52 & 13.8 \\
Specialists Hospital & 44 & 11.7 \\
Comprehensive Health Centre & 8.0 \\
Private Hospital & 30 & 9.6 \\
Others & 36 & 4.3 \\
& 16 & \\
\hline Number of years of practice & & 43.4 \\
$1-5$ & 163 & 21.3 \\
$6-10$ & 80 & 12.5 \\
$11-15$ & 47 & 9.0 \\
$16-20$ & 34 & 13.8 \\
Above 20 & 52 &
\end{tabular}

\section{Waste managements in health facilities}

Most respondents 141 (37.5\%) dispose their wastes in medical waste bin, 60 (16.0\%) use LAWMA, $44(11.7 \%)$ use incinerators, 42 (11.2\%) openly burn theirs, while $22(5.9 \%)$ bury their wastes within their hospital premises (Figure 1). The percentage of respondents disposing vials and ampoules of anticancer drugs in medical waste bin was $39.7 \%$ while $15.1 \%$ buried them in the hospital premises, $12.3 \%$ burn them openly, $11 \%$ dispose them through LAWMA, approximately $10 \%$ through NAFDAC while $6.8 \%$ use incineration (Figure 2). The two most common method of disposing packaging of medicine cited by respondents were through medical waste bin, 117 (31.1\%) and open burning, 114 (30.3\%) while only $1.6 \%$ use incineration (Figure 3 ). $152(40.4 \%)$ return them directly to the manufacturers, $79(21.0 \%)$ mix them with medical waste, sharps or any other form of waste, $72(19.1 \%)$ return the drugs to sales representatives, 63 (16.8\%) use reverse distribution (Figure 4). 155 (41.2\%) of the respondents return expired drugs directly to the pharmaceutical manufacturers, $75(19.9 \%)$ return to sales representatives and 71 (18.9\%) mix expired drugs with medical waste, sharps and other forms of waste (Figure 5). Nearly one third of the respondents 118 (31.4\%) returned expired controlled drugs to suppliers, 73(19.4\%) dispose through NAFDAC, 51(13.6\%) dispose in medical waste bin (Figure 6).

The most frequent way of pharmaceutical waste disposal across all the facilities is to put them in brown biohazard bag (19.68\%) closely followed by the use of red biohazard bags while (19.95\%) while burying within premises was the least method employed, (2.93\%), (Table 2). In tertiary institutions, $45.8 \%$ dispose their wastes in medical waste bin, $15.3 \%$ through incineration and $11.1 \%$ through LAWMA while $2.8 \%$ bury wastes within their premises. Most other facilities also dispose wastes generated in medical waste bins and through LAWMA while only few bury their wastes in their premises (Table 3). The most common method of waste disposal across all level of experience is the use of medical waste bin. For those practice within $1-5$ years, the second most common waste disposal method is open burning $23(14.1 \%)$ while the least method in this group is by burying wastes within premises. But for those who have been in practice for $6-10$ and $11-15$ years, the second most common 
DOI: $10.21522 /$ TIJPH.2013.06.03.Art011

ISSN: $2520-3134$

method use is though LAWMA with $19(23.8 \%)$ and $10(21.3 \%)$ respectively while. Those that have been in practice above 20 years use incinerators more than those below 20 years in practice (Table 4 ).

\section{Concentration of various pharmaceuticals detected by HPLC in tap water, waste water and sludge}

There was no amoxillin trihydrate discovered in tap water sample while $0.634 \mathrm{ug} / \mathrm{L}$ and $6.791 \mathrm{ug} / \mathrm{g}$ were found in waste water and sludge respectively. On the other hand, the amount of Clavlnic acid present in tap water was $0.203 \mathrm{ug} / \mathrm{L}$ but absent in both waste water and sludge water respectively. The concentration of Ciprofloxacin Hydrochloride in waste water was $0.264 \mathrm{ug} / \mathrm{L}, 6.353 \mathrm{ug} / \mathrm{g}$ in sludge but absent in tap water (Table 5). No diclofenac was deducted in tap water and sludge but the amount present in waste water was $0.409 \mathrm{ug} / \mathrm{L}$. In tap water, Paracetamol concentration was $0.00379 \mathrm{ug} / \mathrm{L}$ and $0.01196 \mathrm{~g} / \mathrm{L}$ in waste water while the quantity seen in sludge was $0.55768 \mathrm{ug} / \mathrm{L}$ (Table 6).

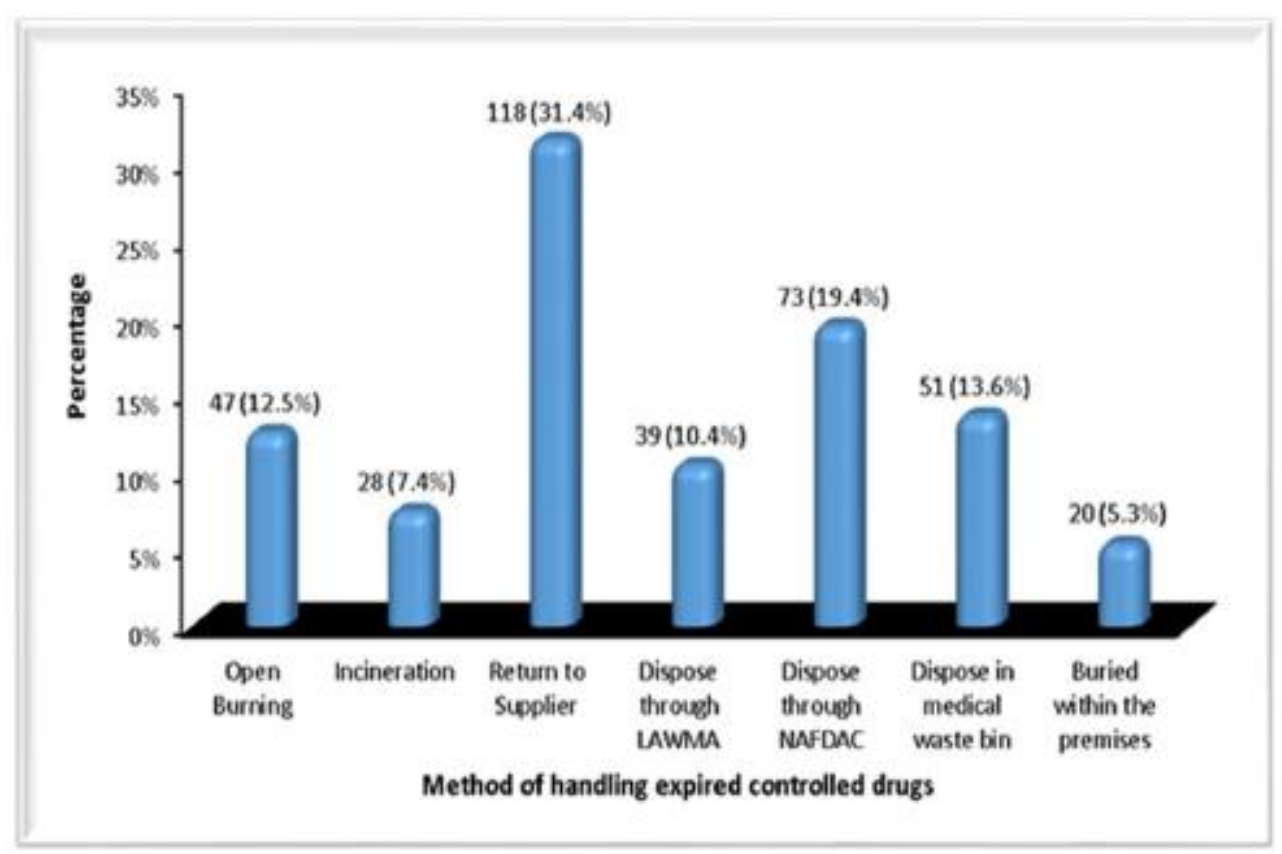

Figure 1. Methods of handling expired controlled drugs

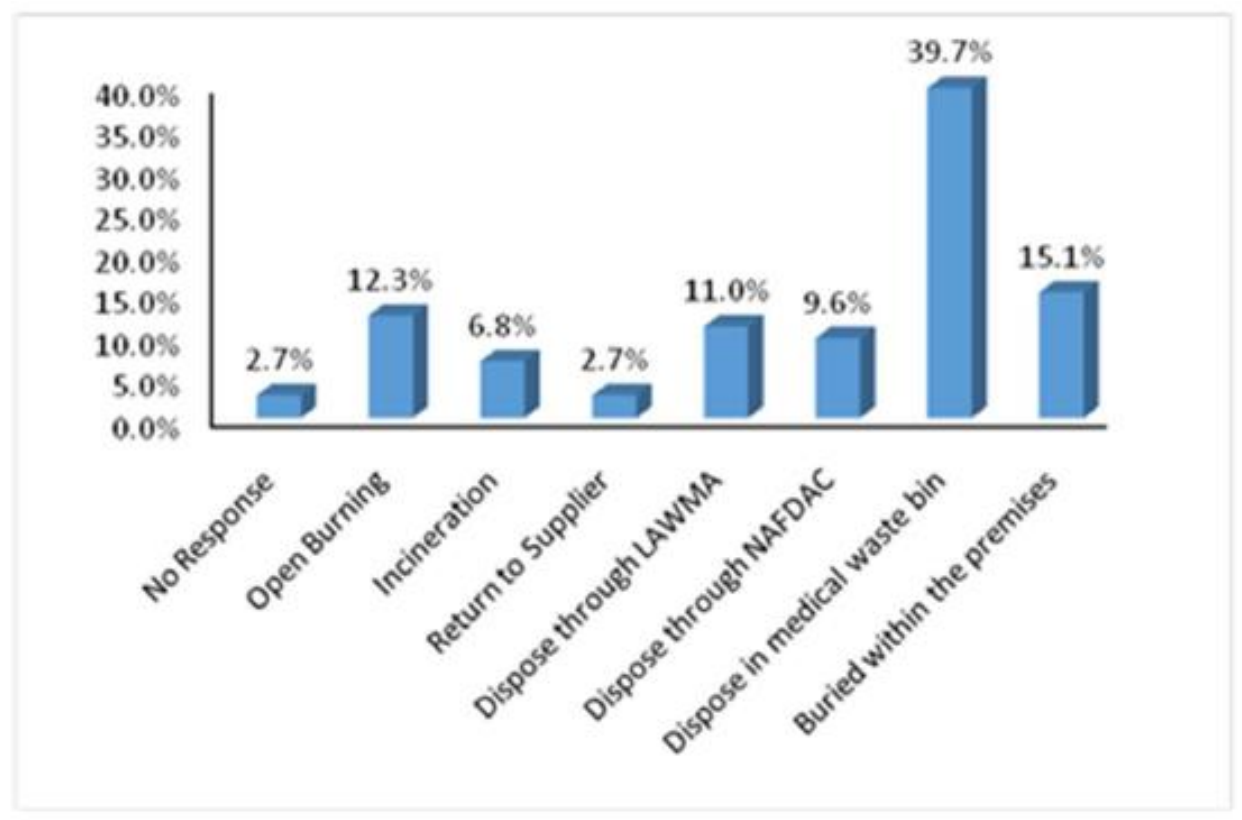

Figure 2. Methods of disposing vials/ampoules of injectable anticancer drugs 
Texila International Journal of Public Health

Volume 6, Issue 3, Sep 2018

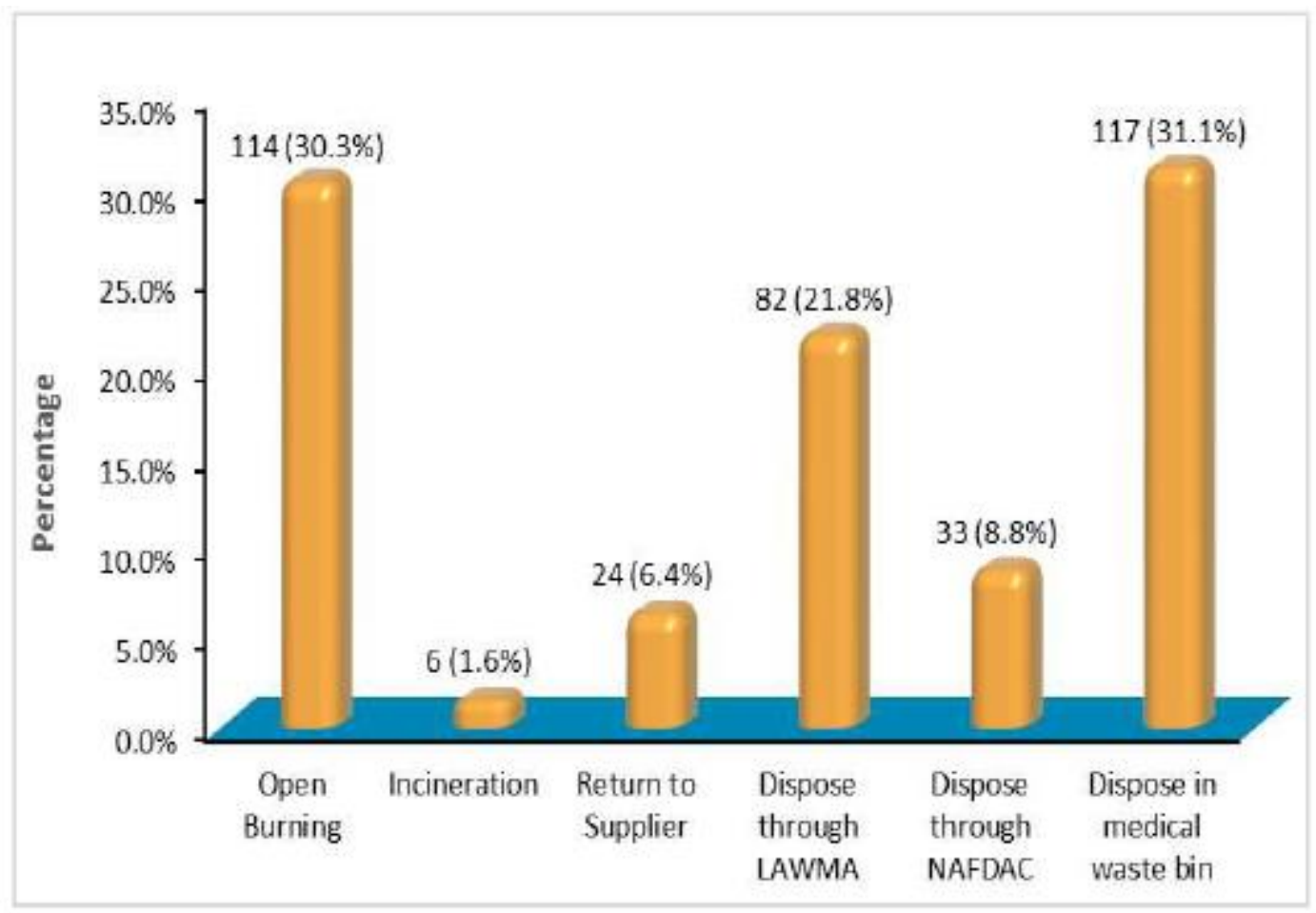

Figure 3. Methods of disposing packaging of medicine and other pharmaceutical materials

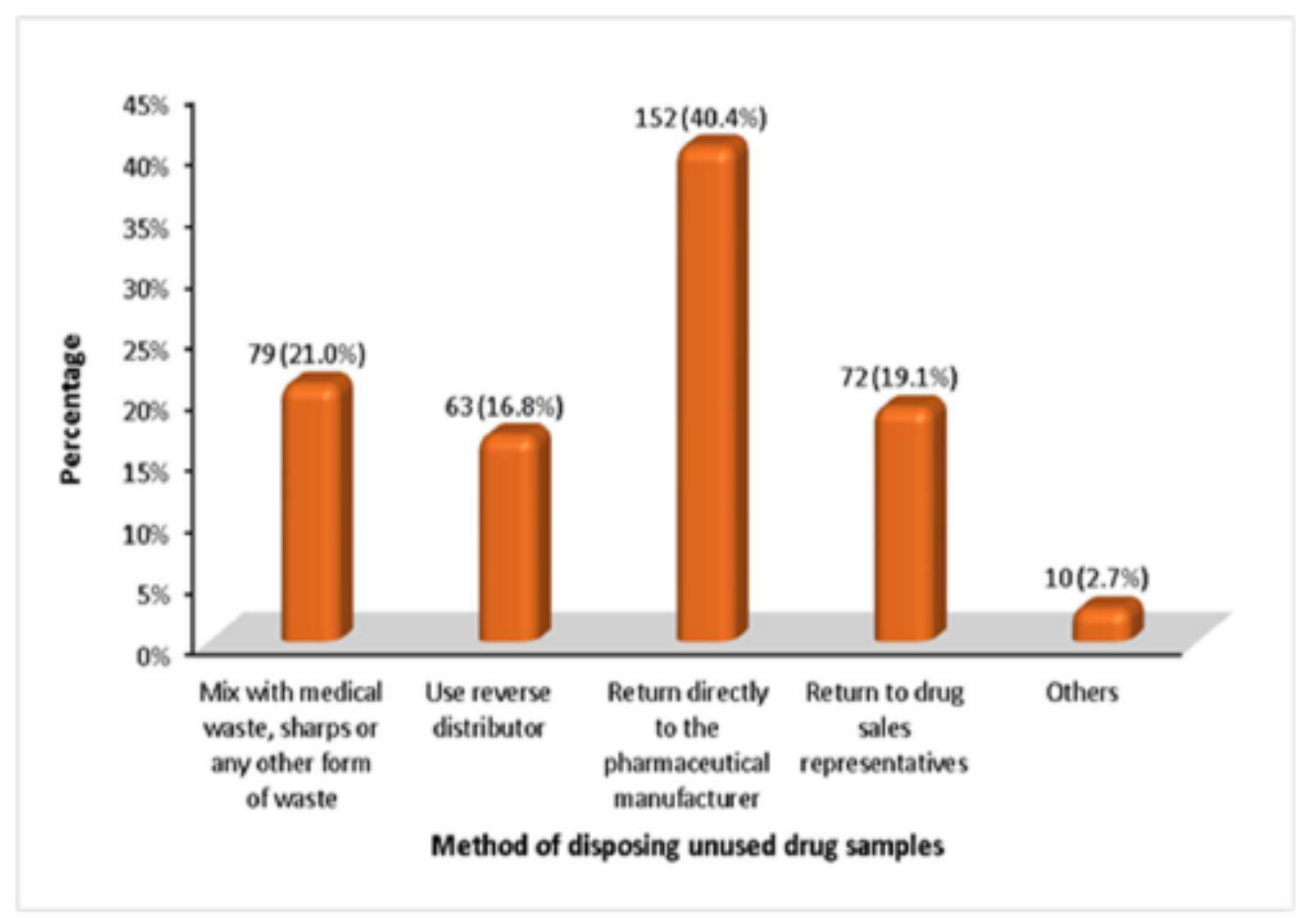

Figure 4. Methods of disposing unused drug samples 
DOI: $10.21522 /$ TIJPH.2013.06.03.Art011

ISSN: $2520-3134$

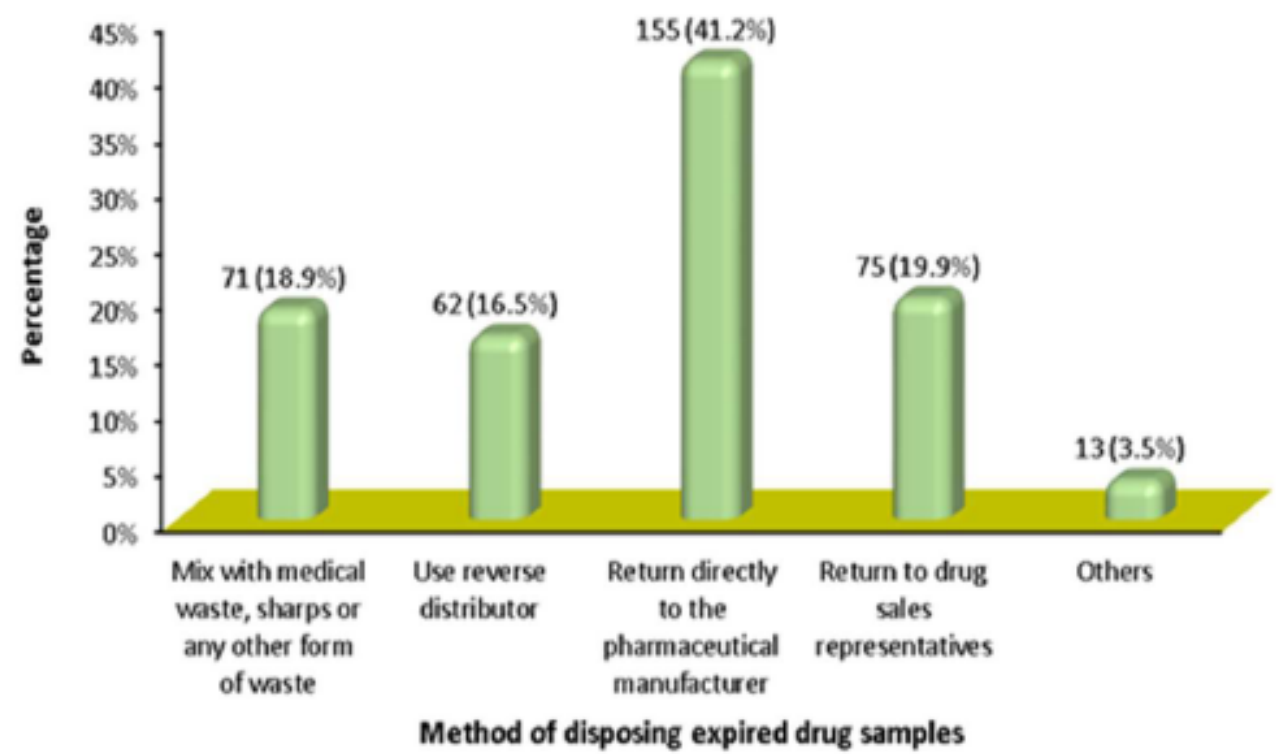

Figure 5. Methods of disposing expired drug samples

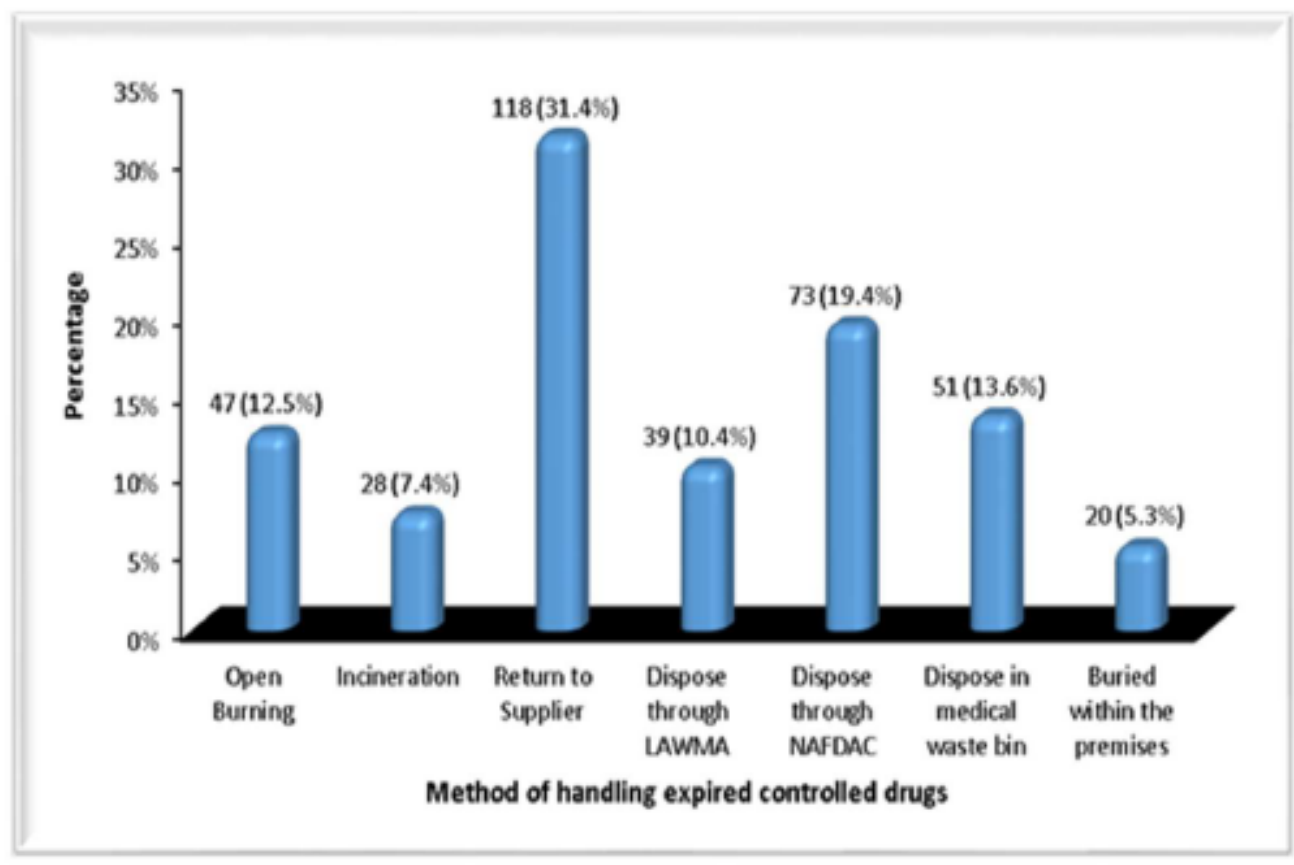

Figure 6. Methods of handling expired controlled drugs

Table 2. General methods employed in pharmaceutical wastes disposal across health facilities

\begin{tabular}{lcc}
\hline Response & Frequency & Percentage \\
\hline Pour/flush down the drain & 43 & $11.44 \%$ \\
& & \\
Put in regular garbage & 73 & $19.41 \%$ \\
\hline
\end{tabular}




$\begin{array}{lcc}\text { Put in red biohazard bag } & 75 & 19.95 \% \\ \text { Put in yellow biohazard bag } & 74 & 19.68 \% \\ \text { Put in brown biohazard bag } & 60 & 15.96 \% \\ \text { Put in black biohazard bag } & 74 & 19.68 \% \\ \text { Put in sharp container } & 54 & 14.36 \% \\ \begin{array}{l}\text { Burnt in open container } \\ \begin{array}{l}\text { Burnt within premises with } \\ \text { general waste }\end{array}\end{array} & 28 & 7.45 \% \\ \begin{array}{l}\text { Buried within or near the } \\ \text { premises }\end{array} & 11 & 4.52 \% \\ \begin{array}{l}\text { Carried away by LAWMA for } \\ \text { destruction in the presence of } \\ \text { company's staff }\end{array} & 71 & 2.93 \% \\ \begin{array}{l}\text { Burnt in the presence of } \\ \text { NAFDAC or LASEPA and } \\ \text { company's staff }\end{array} & 17 & 18.88 \% \\ \end{array}$


DOI: $10.21522 / \mathrm{TIJPH} .2013 .06 .03 . A r t 011$

ISSN: 2520-3134

Table 3. Method of waste disposal across health institutions $(p=0.09)$

\begin{tabular}{|c|c|c|c|c|c|c|c|}
\hline \multirow{2}{*}{$\begin{array}{c}\text { Method of } \\
\text { waste } \\
\text { disposal }\end{array}$} & \multicolumn{7}{|c|}{ What type of health facility do you work for? (\%) } \\
\hline & $\begin{array}{l}\text { Tertiary } \\
\text { Hospital }\end{array}$ & $\begin{array}{l}\text { General } \\
\text { Hospital }\end{array}$ & $\begin{array}{l}\text { Specialist } \\
\text { Hospital }\end{array}$ & $\begin{array}{c}\text { Basic } \\
\text { Health } \\
\text { Centre }\end{array}$ & $\begin{array}{l}\text { Comprehensive } \\
\text { Health Centre }\end{array}$ & $\begin{array}{l}\text { Private } \\
\text { Hospital }\end{array}$ & Others \\
\hline $\begin{array}{c}\text { Open } \\
\text { Burning }\end{array}$ & $7(9.7 \%)$ & $10(7.9 \%)$ & $4(7.7 \%)$ & $10(22.7 \%)$ & $3(10.0 \%)$ & $7(19.4 \%)$ & $1(6.3 \%)$ \\
\hline Incineration & $\begin{array}{c}11 \\
(15.3 \%)\end{array}$ & $15(11.9 \%)$ & $10(19.2 \%)$ & $3(6.8 \%)$ & $2(6.7 \%)$ & $3(8.3 \%)$ & - \\
\hline $\begin{array}{l}\text { Return to } \\
\text { Supplier }\end{array}$ & $4(5.6 \%)$ & $14(11.1 \%)$ & $8(15.4 \%)$ & $3(6.8 \%)$ & $3(10.0 \%)$ & $4(11.1 \%)$ & $2(12.5 \%)$ \\
\hline $\begin{array}{l}\text { Dispose } \\
\text { through } \\
\text { LAWMA }\end{array}$ & $\begin{array}{c}8 \\
(11.1 \%)\end{array}$ & $20(15.9 \%)$ & $4(7.7 \%)$ & $12(27.3 \%)$ & $9(30.0 \%)$ & $4(11.1 \%)$ & $3(18.8 \%)$ \\
\hline $\begin{array}{l}\text { Dispose } \\
\text { through } \\
\text { NAFDAC }\end{array}$ & $7(9.7 \%)$ & $9(7.1 \%)$ & $5(9.6 \%)$ & $2(4.5 \%)$ & $1(3.3 \%)$ & $5(13.9 \%)$ & - \\
\hline $\begin{array}{c}\text { Dispose in } \\
\text { medical } \\
\text { waste bin }\end{array}$ & $\begin{array}{c}33 \\
(45.8 \%)\end{array}$ & $46(36.5 \%)$ & $18(34.6 \%)$ & $12(27.3 \%)$ & $11(36.7 \%)$ & $13(36.1 \%)$ & $8(50.0 \%)$ \\
\hline $\begin{array}{l}\text { Buried within } \\
\text { the premises }\end{array}$ & $2(2.8 \%)$ & $12(9.5 \%)$ & $3(5.8 \%)$ & $2(4.5 \%)$ & $1(3.3 \%)$ & - & $2(12.5 \%)$ \\
\hline Total & $\begin{array}{c}72 \\
100.0 \%)\end{array}$ & $\begin{array}{c}126 \\
(100.0 \%)\end{array}$ & $52(100.0 \%)$ & $\begin{array}{c}44 \\
(100.0 \%)\end{array}$ & $30(100.0 \%)$ & $\begin{array}{c}36 \\
(100.0 \%)\end{array}$ & $\begin{array}{c}16 \\
(100.0 \%)\end{array}$ \\
\hline
\end{tabular}


Table 4. Method of waste disposal with number of years in practice $(\mathrm{p}=0.038)$

\begin{tabular}{|c|c|c|c|c|c|}
\hline \multirow{2}{*}{ Method of waste disposal } & \multicolumn{5}{|c|}{ Number of years of practice $(\%)$} \\
\hline & $1-5$ & $6-10$ & $11-15$ & $16-20$ & $>20$ \\
\hline Open Burning & $23(14.1 \%)$ & $8(10.0 \%)$ & $1(2.1 \%)$ & $4(11.8 \%)$ & $6(11.5 \%)$ \\
\hline Incineration & $18(11.0 \%)$ & $8(10.0 \%)$ & $6(12.8 \%)$ & $2(5.9 \%)$ & $10(19.2 \%)$ \\
\hline Return to Supplier & $20(12.3 \%)$ & $6(7.5 \%)$ & $2(4.3 \%)$ & $5(14.7 \%)$ & $5(9.6 \%)$ \\
\hline $\begin{array}{l}\text { Dispose through } \\
\text { LAWMA }\end{array}$ & $20(12.3 \%)$ & $19(23.8 \%)$ & $10(21.3 \%)$ & $2(5.9 \%)$ & $9(17.3 \%)$ \\
\hline $\begin{array}{l}\text { Dispose through } \\
\text { NAFDAC }\end{array}$ & $12(7.4 \%)$ & $4(5.0 \%)$ & $5(10.6 \%)$ & $6(17.6 \%)$ & $2(3.8 \%)$ \\
\hline $\begin{array}{l}\text { Dispose in medical waste } \\
\text { bin }\end{array}$ & $59(36.2 \%)$ & $35(43.8 \%)$ & $17(36.2 \%)$ & $14(41.2 \%)$ & $16(30.8 \%)$ \\
\hline $\begin{array}{l}\text { Buried within the } \\
\text { premises }\end{array}$ & $11(6.7 \%)$ & - & $6(12.8 \%)$ & $1(2.9 \%)$ & $4(7.7 \%)$ \\
\hline Total & $163(100.0 \%)$ & $80(100.0 \%)$ & $47(100.0 \%)$ & $34(100.0 \%)$ & $\begin{array}{l}52 \\
(100.0 \%) \\
\end{array}$ \\
\hline
\end{tabular}


DOI: $10.21522 /$ TIJPH.2013.06.03.Art011

ISSN: $2520-3134$

Table 5. Concentration of Augmentin (amoxicillin and Clavulanate) and Ciprofloxacin Hydrochloride detected in tap water, waste water and sludge

\begin{tabular}{llll}
\hline Sample & $\begin{array}{l}\text { Amoxicillin } \\
\text { Trihydrate } \\
\text { Concentration }\end{array}$ & $\begin{array}{l}\text { Clavulanic acid } \\
\text { Concentration }\end{array}$ & $\begin{array}{l}\text { Ciprofloxacin } \\
\text { Hydrochloride } \\
\text { Concentration }\end{array}$ \\
\hline Tap Water & - & $0.203 \mathrm{ug} / \mathrm{L}$ & - \\
Waste & $0.634 \mathrm{ug} / \mathrm{L}$ & - & $0.264 \mathrm{ug} / \mathrm{L}$ \\
Water & & - & $6.353 \mathrm{ug} / \mathrm{g}$ \\
Sludge & $6.791 \mathrm{ug} / \mathrm{g}$ & - & \\
\hline
\end{tabular}

Table 6. Concentration of diclofenac and paracetamol detected in tap water, waste water and sludge

\begin{tabular}{lll}
\hline Samples & Diclofenac Concentration & $\begin{array}{l}\text { Paracetamol } \\
\text { Concentration }\end{array}$ \\
\hline Tap Water & - & $0.00379 \mathrm{ug} / \mathrm{L}$ \\
Waste Water & $0.409 \mathrm{ug} / \mathrm{L}$ & $0.01196 \mathrm{~g} / \mathrm{L}$ \\
Sludge & - & $0.55768 \mathrm{ug} / \mathrm{L}$ \\
\hline
\end{tabular}

\section{Discussion}

The main objective of this study is to identify the major methods used in the management of pharmaceutical wastes in the health facilities in Lagos state, Nigeria and to identify the presence of pharmaceutical wastes in waste water, tap water and sludge in the environment of one of the major health facilities. This study comprised 376 respondents from various health institutions in Lagos State, South West, Nigeria of which the majority were females, $68.4 \%$. Most frequent age group was $31-40$ years, $42.3 \%$, followed by $29.0 \%$ for $21-30,16.5 \%$ for $41-50$ and $10.6 \%$ for above 50 years while the least frequent age group was 20 and below, $1.6 \%$. The is similar to the findings of Awodel et al., (2016) in which the majority $53.3 \%$ of the respondents were females with mean and the most frequent age was $31-35$ with $24.8 \%$ respondents while the least frequent age was $20-25$ with $8.6 \%$ (Awodele et al., 2016). Also, majority $43.4 \%$ of the respondents have been in service for less than 5 years, $21.3 \%$ have been practicing their professions between $6-10$ years, $13.8 \%$ have spent over 20 years in their professions while 9\% have spent between 16 - 20 years. Similarly, Awodele et al., (2016) reported that majority (33.3\%) of the respondents in a similar research conducted in Lagos State have been working in the hospital for $1-5$ years while $7.6 \%$ were between $16-20$ years in the hospital (Awodele et al., 2016).

Approximately $34 \%$ of the respondents worked in general hospitals, $19.1 \%$ worked in tertiary hospitals, $13.8 \%$ in specialist hospitals, $11.7 \%$ in basic health centres, $9.6 \%$ in private hospital while $8.0 \%$ and $164.3 \%$ were staffs of comprehensive health centers and other health institutions respectively. Majority (37.5\%) of the correspondent dispose their pharmaceutical waste in medical waste bin. This finding is similar to the findings of Ngwuluka et al., (2011) in which the majority of the companies used medical waste bin to dispose their pharmaceutical wastes. Other methods mentioned included Lagos State Waste Management Authority (LAWMA), Incineration, open burning and others burn in hospital premises (Ngwuluka et al., 2011).

Most common methods of disposing packaging of medicines by respondents are through medical waste bin (31.1\%) and open burning. Other methods are through LAWMA, returning to manufacturer, incineration and NAFDAC. In a study in Kuwait among pharmacists, throwing unwanted medicines in the trash was the main method of disposal by majority of the respondents (73\%), this tally with findings 
in this study where 60 (36\%) of respondents that work in the pharmacy unit dispose pharmaceutical waste in medical waste bin (Abahussain et al., 2006).

The result of the study shows that unused drugs are returned directly to the supplier (40.4\%), mixed with medical waste, sharps or any form of waste. Expired drugs are returned directly to the pharmaceutical manufacture (41.2\%) and drug sales representative (19.9\%). Expired control drugs were majorly dispose by returning to supplier (31.4\%) and disposed through NAFDAC (19.4\%). As reported by Kalyva, (2017) a survey carried out in the UK investigating the household disposal of unused and expired pharmaceuticals interviewed members of 400 households, predominantly from south-eastern England, and was the basis for a conceptual model aiming to assess the pathways of human pharmaceuticals into the environment (Kalyva, 2017). The model demonstrated that the disposal of unused pharmaceuticals, either by household waste or via the sewerage, may be a prominent route that requires greater attention (Bound and Voulvoulis, 2005). More than half of the patients asked in a study conducted in the US reported storing unused and expired medications in their homes, and more than half had flushed them down a toilet. Only $22.9 \%$ reported returning medication to a pharmacy for disposal. Less than $20 \%$ had ever been given advice about medication disposal by a health care provider (Seehusen and Edwards, 2006). Thirty-nine-point seven percent (39.7\%) of the vials/ampoules of anticancer drug are disposed in the medical waste bin $15.1 \%$ buried with premises and $12.3 \%$ by open burning. Most of the respondents in this study dispose off pharmaceutical waste in their facility in biohazard bags (red, 19.95\%), yellow and black (19.68\%) and regular garbage (19.41\%). This is similar to a study carried out among health care professionals in south India where $38.6 \%$ of doctors dispose pharmaceuticals in dustbin, and 24.6 percent flush them down to the sink. 59.2 percent of dental doctors disposing in dustbin and 20.2 flushing them to the sink. Among nurse's 54.2 percent throw in dustbin and 30.2 flushing them down to the sink and toilet (Radhakrishna et al., 2014).

The packaging materials for pharmaceuticals are also part of pharmaceutical waste. The awareness among respondents of packaging materials reveals that nearly $50 \%$ of the respondents were aware of PVC as packaging materials; other packaging material identified included paper packaging, plastic packaging and cardboard packaging. There was no amoxillin trihydrate discovered in tap water sample while $0.634 \mathrm{ug} / \mathrm{L}$ and $6.791 \mathrm{ug} / \mathrm{g}$ were found in waste water and sludge respectively. On the other hand, the amount of Clavlnic acid present in tap water was $0.203 \mathrm{ug} / \mathrm{L}$ but absent in both waste water and sludge. The concentration of Ciprofloxacin Hydrochloride in waste water was $0.264 \mathrm{ug} / \mathrm{L}, 6.353 \mathrm{ug} / \mathrm{g}$ in sludge but absent in tap water. Insufficiently treated wastewaters from pharmaceutical production in one of the world's largest centres for bulk drug production located in India resulted in very high concentrations of ciprofloxacin (up to $6.5 \mathrm{mg} \mathrm{dm}^{-3}$ ) in freshwater lakes (Fick et al., 2009). This value is far higher than $0.264 \mathrm{ug} / \mathrm{L}$ detected in this study, notwithstanding, the risk attached to the presence of this drug in environment cannot be over emphasized. No diclofenac was detected in tap water and sludge but the amount present in waste water was $0.409 \mathrm{ug} / \mathrm{L}$. Diclofenac was shown to be significantly biodegraded only when the sludge retention time was at least 8 days (Kreuzinger et al., 2004). Studies detected the sorption behavior of carbamazepine, diclofenac and ibuprofen in sandy sediments and showed that sorption coefficients were generally quite low (Scheytt et al., 2005). For instance, some antibiotics, e.g. tetracyclines, are known to tend to bind to soil particles or to form complexes with ions that are present (ter et al., 2006). The sorption of antibiotics is especially affected by the amount and nature of free and suspended particles in the water phase, soil organic matter and soil (Thiele-Bruhn, 2003). Diclofenac residues and renal disease were reproduced experimentally in oriental white-backed vultures by direct oral exposure and through feeding vultures' diclofenac-treated livestock (Oaks et al., 2002). In tap water, Paracetamol concentration was $0.00379 \mathrm{ug} / \mathrm{L}$ and $0.01196 \mathrm{~g} / \mathrm{L}$ in waste water while the quantity seen in sludge was $0.55768 \mathrm{ug} / \mathrm{L}$. Previous findings unsurprisingly indicate that treated wastewater is an important route for the introduction of various xenobiotic pharmaceuticals to surface and groundwater. A recent study reported the occurrence of paracetamol (up to $83 \mathrm{ngdm}^{-3}$ ) in groundwater in the vicinity of Gdańsk (Caban et al., 2015).

\section{Conclusion}

Pharmaceutical wastes management is a very important area of medical practices. Lagos state government has taken the initiatives to have a well-organized system of collecting and treating waste. 
The State has also taken further steps by providing the needed items like the different colored containers, liners to the hospitals. LAWMA also collects the waste for final disposal at little cost so that the hospitals can be encouraged to segregate and collect their waste appropriately. Despite these giant strides by the government of Lagos State, our findings revealed that most of the health facilities in Lagos use waste bins for pharmaceutical waste management. Only few hospitals engage LAWMA and NAFDAC regularly for waste disposal. It was found that some of the hospitals still embark on open burning of medical wastes while some still bury wastes in their hospital premises. We can therefore conclude that the presence of pharmaceutical wastes (drugs) in tap water, waste water and sludge in hospital environments is connected with waste management methods among other means mentioned in the literature. We therefore advocate for continuous training of hospital staff on pharmaceutical wastes management. There is also a need for awareness of waste management system amongst the patient/community in order to prevent nosocomial infections and environmental hazards. Policy and regulation guidelines should be provided to all the three tiers of government (federal, state and local government) so as to improve waste management practices throughout the country as also recommended by Awodele et al., 2016).

\section{References}

[1]. Abahussain, E. A., Ball, D. E., \& Matowe, W. C. (2006). Practice and opinion towards disposal of unused medication in Kuwait. Medical Principles and Practice, 15(5), 352-357.

[2]. Awodele, O., Adewoye, A. A., \& Oparah, A. C. (2016). Assessment of medical waste management in seven hospitals in Lagos, Nigeria. BMC public health, 16(1), 269.

[3]. Bound, J. P., \& Voulvoulis, N. (2005). Household disposal of pharmaceuticals as a pathway for aquatic contamination in the United Kingdom. Environmental health perspectives, 113(12), 1705.

[4]. Caban M., Lis E., Kumirska J., Stepnowski P., (2015). Determination of pharmaceutical residues in drinking water in Poland using a new SPE-GC-MS(SIM) method based on Speedisk extraction disks and DIMETRIS derivatization, Sci. Total. Environ. 538: 402-411.

[5]. Fick J., Söderström H., Lindberg R.H., Phan C., Tysklind M. \& Larsson D.G. (2009), Contamination of surface, ground, and drinking water from pharmaceutical production, Environ. Toxicol. Chem. 28(12): 25222527.

[6]. Jovanović, V., Manojlović, J., Jovanović, D., Matic, B., \& Đonović, N. (2016). Management of pharmaceutical waste in hospitals in Serbia-challenges and the potential for improvement. INDIAN JOURNAL OF PHARMACEUTICAL EDUCATION AND RESEARCH, 50(4), 695-702.

[7]. Kalyva, M. (2017). Fate of pharmaceuticals in the environment-A review. (accessed: 07/05/2018).

[8]. Kreuzinger, N., Clara, M., Strenn, B. and Kroiss, H., (2004). Relevance of the sludge retention time (SRT) as design criteria for wastewater treatment plants for the removal of endocrine disruptors and pharmaceuticals from wastewater. Water Science and Technology, 50(5), pp.149-156.

[9]. Ngwuluka, N. C., Ochekpe, N. A., \& Odumosu, P. O. (2011). An assessment of pharmaceutical waste management in some Nigerian pharmaceutical industries. African Journal of Biotechnology, 10(54), 1125911264.

[10]. Oaks, J.L., Gilbert, M., Virani, M.Z., Watson, R.T., Meteyer, C.U., Rideout, B.A., Shivaprasad, H.L., Ahmed, S., Chaudhry, M.J.I., Arshad, M. and Mahmood, S., (2002). Diclofenac residues as the cause of vulture population decline in Pakistan. J. Zoological Systematics and Evolutionary Research, 40, pp.65-81.

[11]. Patneedi, C. B., Prasadu, D., Sharma, R. S. K., Sekhar, D. C., \& Rao, D. V. (2015). MICROWAVE MEDIATED SYNTHESIS IN PHARMACEUTICAL CHEMISTRY.

[12]. Priya, P., (2017). Management of Pharmaceutical Wastes. Journal of drug discovery and therapeutics, 5(3)

[13]. Radhakrishna, L., Nagarajan, P., Vijayanandhan, S. S., \& Ponniah, T. (2014). Knowledge, Attitude and practice (KAP) towards disposal of medicines: A qualitative study among health care professionals in South India. Wld J Pharm Res, 3, 1955-63.

[14]. Scheytt, T., Mersmann, P., Lindstädt, R. and Heberer, T., (2005). Determination of sorption coefficients of pharmaceutically active substances carbamazepine, diclofenac, and ibuprofen, in sandy sediments. Chemosphere, 60(2), pp.245-253.

[15]. Seehusen, D. A., \& Edwards, J. (2006). Patient practices and beliefs concerning disposal of medications. The Journal of the American Board of Family Medicine, 19(6), 542-547. 
Texila International Journal of Public Health Volume 6, Issue 3, Sep 2018

[16]. ter Laak, T.L. and Gebbink, W.A., (2006). Estimation of soil sorption coefficients of veterinary pharmaceuticals from soil properties. Environmental toxicology and chemistry, 25(4), pp.933-941.

[17]. Thiele-Bruhn, S., (2003). Pharmaceutical antibiotic compounds in soils-a review. Journal of Plant Nutrition and Soil Science, 166(2), pp.145-167.

[18]. World Health Organization. (2017). Safe management of wastes from health-care activities: a summary. 